Division of Geological \& Geophysical Surveys

RAW-DATA FILE 2014-1

\title{
MERCURY INJECTION CAPILLARY PRESSURE RESULTS FROM OUTCROP SAMPLES IN THE KAGUYAK, NAKNEK, AND WEST FORELAND FORMATIONS, INISKIN PENINSULA REGION, ALASKA
}

by

Andrea M. Loveland and PetroTech Associates

$\$ 2.00$

FEBRUARY 2014

THIS REPORT HAS NOT BEEN REVIEWED FOR

TECHNICAL CONTENT OR FOR CONFORMITY TO THE EDITORIAL STANDARDS OF DGGS

Released by

STATE OF ALASKA

DEPARTMENT OF NATURAL RESOURCES

Division of Geological \& Geophysical Surveys

3354 College Road

Fairbanks, Alaska 99709-3707 



\section{MERCURY INJECTION CAPILLARY PRESSURE RESULTS FROM OUTCROP SAMPLES IN THE KAGUYAK, NAKNEK, AND WEST FORELAND FORMATIONS, INISKIN PENINSULA REGION, ALASKA}

by

Andrea M. Loveland ${ }^{1}$ and PetroTech Associates ${ }^{2}$

${ }^{1}$ Division of Geological \& Geophysical Surveys, 3354 College Road, Fairbanks, Alaska 99709-3707; andrea.loveland@alaska.gov

${ }^{2}$ PetroTech Associates, 11767 Katy Freeway, Suite 320, Houston, Texas 77079

\section{INTRODUCTION}

This report summarizes mercury injection capillary pressure (MICP) data for 36 outcrop samples collected from the Kaguyak,Naknek, and West Foreland formations in the Iniskin Peninsula region of Cook Inlet. All samples were collected from measured stratigraphic section, with the exception of samples 10DL009b, 10MAW005c, 10MAW007b, and 10MAW007e (fig. 1). Measured section sample coordinates represent the location of the bottom of the stratrigraphic measured section. All samples were analyzed by PetroTech Associates, Houston, TX.

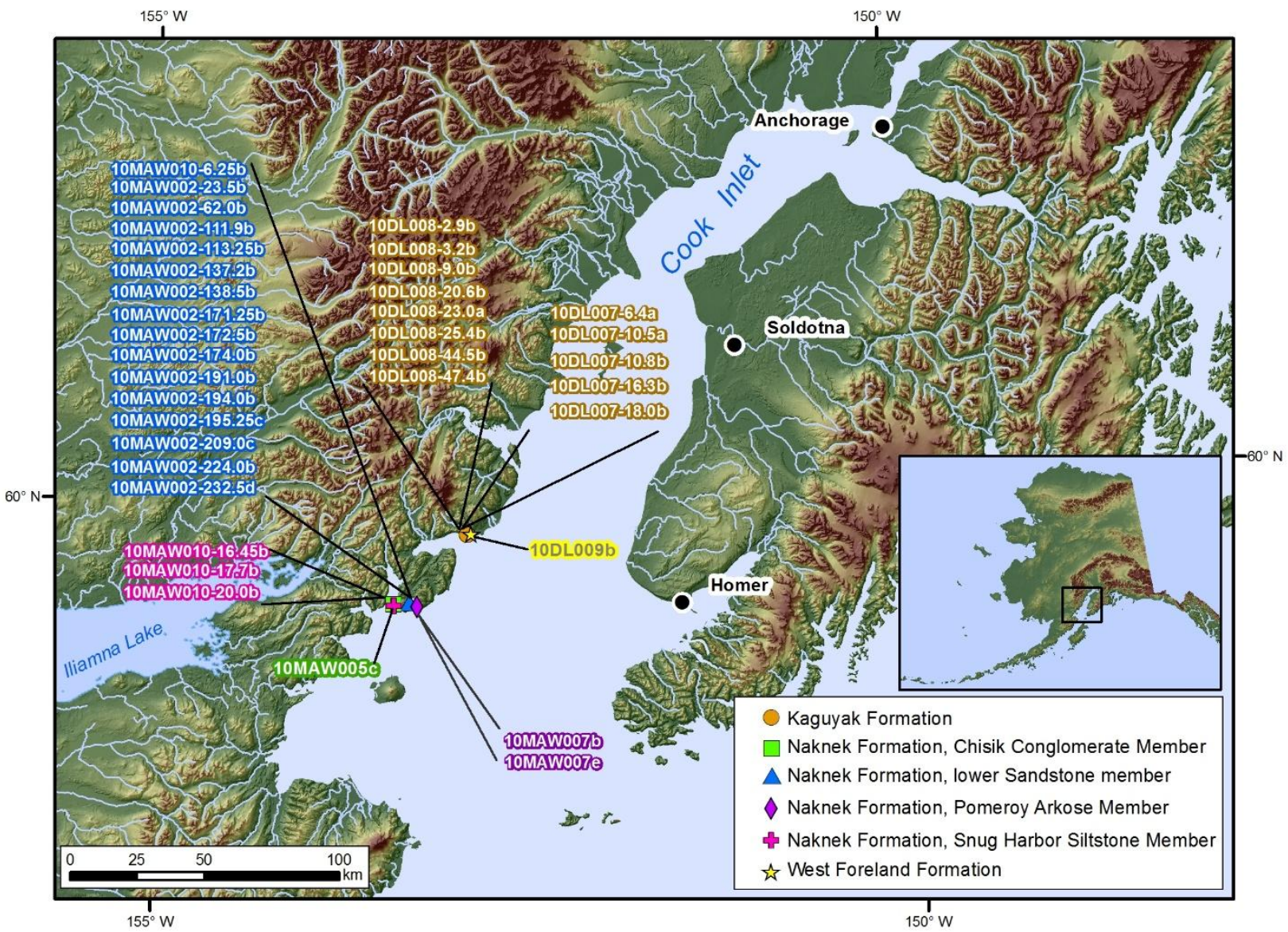

Figure 1. Shaded-relief map of the Cook Inlet area, showing the locations from which 36 outcrop samples were collected for MICP analysis. 


\section{DATA FILES}

The data for this publication is provided in its native spreadsheet format. The citation index page for this publication is http://dggs.alaska.gov/pubs/id/27021. The digital dataset includes:

- Sample names, coordinates, and the formation from which samples were collected

- Per-sample pore aperture size distribution charts

- Formation pore volume graphs and data

- Pore system properties of each formation from which samples were analyzed

A detailed description of the digital data files can be found in the associated metadata file.

The following pages include correspondence from PetroTech Associates describing the methods used in MICP analyses of the samples in this report, a brief summary of the data, and references cited. 


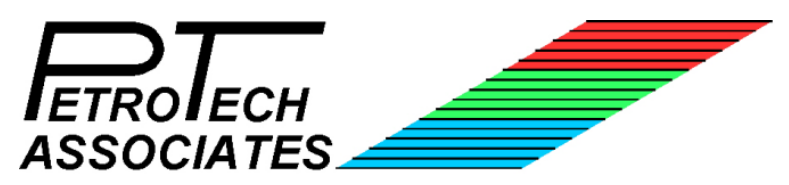

11767 Katy Freeway, Suite 320

Houston, Texas 77079

Tel: 281.558.3996 Fax: 281.558.3998

January 18, 2011

Robert Gillis

Alaska Division of Geological \& Geophysical Surveys

3354 College Road

Fairbanks, AK 99709

\section{Dear Bob,}

PetroTech has completed high-pressure mercury injection capillary pressure analysis of thirtysix (36) outcrop samples from the Cook Inlet Basin Analysis Program, Lower Cook Inlet, Iniskin Peninsula region. Sample designations, formations and location information are provided in Table 1. For the tables and figures in the report, the samples are separated into three groups: (1) the Kaguyak Fm., Saddle Mountain area (10DL007 and 10DL008), (2) Naknek Fm. Lower sandstone mbr., Oil Bay (10MAW002), and (3) remaining Naknek Fm. samples and West Foreland Fm. sample.

Following receipt of the samples, a representative portion of each was trimmed to fit the sample holders and examined under reflected light microscopy to note any irregularities that might affect the data quality. The rock surfaces were cleaned of any mud or dust and the samples then dried to a constant weight in a low-temperature oven before being analyzed.

During capillary pressure testing, the volume of mercury injected was measured at 118 pressure points from 1.64 to 59,500 psia. These data were then corrected for closure (i.e., mercury conformance to the sample surface). A table of the data and separate plots of cumulative bulk volume and wetting phase saturation versus capillary pressure, as well as the incremental pore aperture size distribution, are included for each sample. Composite plots of the drainage data (Figure 1) and pore aperture size distributions (Figure 2), along with a series of individual pore aperture size distribution plots (Figure 3 ) are provided, as an aid when comparing samples.

Table 2 contains information on the pore space properties including the porosity and permeability values derived from the capillary pressure testing. The reported porosity is based on an Archimedes bulk volume and the closure corrected volume of mercury injected during testing (pore volume). The permeability is estimated using the Swanson equation (SPE, 1981) and the values of cumulative bulk volume and capillary pressure at maximum intrusion. The porosity ranges from $1.88 \%$ to $13.76 \%$. A majority of the samples have $<5 \%$ porosity, with values between $3 \%$ and $5 \%$ most common. Samples described as claystone/shale (nine samples) have an average porosity of $3.95 \%$ and the remaining samples average $5.15 \%$. Permeability is low, with $55 \%$ of the samples having $<0.01 \mathrm{md}$. The claystone/shale rocks are 
the tightest, with a geometric mean permeability of 0.08 microdarcies. Permeability in the remaining samples varies from $0.0002 \mathrm{md}$ to $1.2 \mathrm{md}$, and the geometric mean is $0.015 \mathrm{md}$.

The capillary pressure data displayed in Figures 1 through 3, along with pore structure information in Table 2, shows that there are several pore structures present. Twelve of the samples exhibit some degree of bimodality, with variability reflected in the location of the intrusion peaks within the overall pore aperture size distribution and in the amount of pore volume controlled by each peak. In most of the bimodal pore structures the initial peak is between apertures from 0.1 to 1.0 microns (diameter). The pore space accessed by this portion of the intrusion profile controls permeability, and the larger apertures result in higher overall permeability values. The geometric mean permeability for the bimodal samples is $0.034 \mathrm{md}$. The remaining rocks have unimodal pore structures. The claystone/shale samples have welldefined intrusion profiles, showing that the pore space is accessed through a relatively narrow pore aperture size range. The other unimodal samples have more heterogeneous pore systems as indicated by the broader peaks and presence of a shoulder and/or tail, with the tails generally trailing off toward smaller pore apertures. Median pore aperture size ranges from 0.0066 microns to 0.0172 microns in the claystone/shale, and from 0.0214 microns to 0.4845 microns in the remaining rocks with some sort of unimodal intrusion profile.

The air/mercury capillary entry pressures are highest in the claystone/shale rocks where they average 6,757 psia (range 3,710-10,900 psia). Entry pressure for the other rocks varies from 13 psia to 1,650 psia, with values below 200 psia most common. The high entry pressures in the claystone/shale samples would make them excellent capillary seals-Type $A^{*}$ in the Sneider Classification system.

The claystone/shale rocks were evaluated for potential seal capacity. The air/mercury capillary pressure data were converted to gas/water and oil/water systems assuming a gas/water surface tension of 50 dynes/cm and an oil/water interfacial tension of 30 dynes $/ \mathrm{cm}$. Subsequent conversion to equivalent height was made using the following values (reservoir conditions):

\begin{tabular}{|c|c|c|}
\hline Water Density & Gas Density & Oil Density \\
\hline $1.016 \mathrm{~g} / \mathrm{cc}$ & $0.28 \mathrm{~g} / \mathrm{cc}$ & $0.69 \mathrm{~g} / \mathrm{cc}$ \\
\hline
\end{tabular}

Calculations of potential seal capacity (hydrocarbon column held) were made for hydrocarbon saturations in the seal of $0 \%$ (entry), 5\%,7.5\%, and 10\% and are plotted in Figures 4 and 5 . The value at a saturation of $7.5 \%$ is often used to indicate the point where the hydrocarbon phase in the seal rock is continuous enough to cause the seal to leak and these values are displayed separately in Figures 6 and 7. A file is included that contains the calculations used to convert the air/mercury capillary pressure to height. The fluid properties (densities and surface tensions) used to derive these column heights can be changed in the spreadsheet and the potential seal capacities will be re-calculated and the new values plotted.

Table 3 shows the data for the claystone/shale rocks. The restricted pore structures in these rocks generate high capillary pressures resulting in the excellent seal quality. Using the previously referenced subsurface fluid properties and the capillary pressure at $7.5 \%$ saturation in the seal, these rocks can potentially trap oil columns ranging from approximately 3,700 feet to 9,700 feet (average 6,500 feet). For gas, the column height range from approximately 2,700 feet to 7,100 feet (average 4,800 feet). 
PetroTech has assigned project code PA-1120 to this study. We appreciate the opportunity to provide these services. Please contact us with any comments or questions regarding the data or analytical procedures.

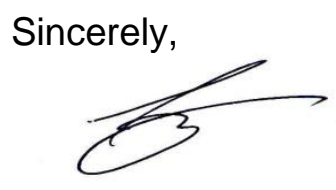

George Bolger

\section{References cited}

Sneider, R.M., 1991, Petrophysical properties of seals, in Surdam, R.C., ed., Seals, Traps, and the Petroleum System: Tulsa, OK, American Association of Petroleum Geologists Memoir 67; 317 p.

Swanson, B.F., 1981, A simple correlation between permeabilities and mercury capillary pressures: Journal of Petroleum Technology, p. 2,498-2,504. 